\title{
PERBEDAAN PURSED LIPS BREATHING DENGAN PURSED LIPS BREATHING DAN LATIHAN EKSTREMITAS TERHADAP KEBUGARAN PADA PASIEN PENYAKIT PARU OBSTRUKTIF KRONIK (PPOK) DI RUMAH SAKIT GRANDMED LUBUK PAKAM TAHUN 2020
}

\section{SABIRIN BERAMPU ${ }^{1}$, ISIDORUS JEHAMAN ${ }^{2}$, RAYNALD IGNASIUS ${ }^{3}$, MIFTAHUL ZANNAH ${ }^{4}$, SRI DAYANTI ${ }^{5}$}

\author{
1,2,3,4,5 INSTITUT KESEHATAN MEDISTRA LUBUK PAKAM TAHUN 2020 \\ Jl. Sudirman No. 38, Kel. Lubuk Pakam Pekan, Kec Lubuk Pakam, Kab. \\ Deli Serdang, Sumatera Utara \\ Email: sabirin.berampu13@gmail.com
}

DOI : $10.35451 /$ jkf.v3i1.511

\begin{abstract}
Chronic Obstructive Pulmonary Disease (COPD) is a chronic lung disease characterized by limited air flow in respiratory tract that is not completely reversible and progressive. Patients with COPD tend to inactivity that occur due to reduced oxygen in the tissues, decreased fitness in helping to improve fitness given Pursed lips breathing treatment and limb training. This study was to determine the difference between pursed lips breathing with pursed lips breathing and exercise extremity on fitness in patients with COPD. The method is a quantitative research with quasi experimental type using Using two groups pre test and posttest design, This research use 18 samples devided into two groups, the control group (Pursed Lips Breathing) and the intervention group (Pursed Lips Breathing And Extremity Exercise) with purposive sampling technique that is adjusted to inclusion and exclusion criteria. Research analysis use independent sample $t$ test showed by $p$-value 0,000 which Means there are differences between in Pursed Lips Breathing with Pursed Lips Breathing and Extremity Exercises Against Fitness in Patients with COPD. The result showed by mean of 17.22 with SD 11.487 and $p$-value $a<(0.002<0.05)$ in the control group (Pursed Lips Breathing) and mean 65,000 with SD 11.990 and $p$-value $a<(0,000<0.05)$ and in intervention group interventions (Pursed Lips Breathing and limb training). Result showed that the average difference in fitness before and after (Pursed Lips Breathing and Extremity Exercises) was greater than in the control group (Pursed Lips Breathing). The conclusion is any difference between Pursed Lips Breathing and Pursed Lips Breathing and Extremity Exercise Against Fitness in Patients with COPD.
\end{abstract}

Keywords: COPD, Fitness, Pursed Lips Breathing And Extremity Exercises 


\section{PENDAHULUAN}

Berdasarkan data Organisasi Kesehatan Dunia (WHO) Global Report on Noncommunicable disease tahun 2014 menyebutkan, penyakit penyebab kematian didunia rata rata adalah penyakit Kardiovaskuler, Pneumonia, Tuberculosis, dan Penyakit Paru Obstruktif Kronik (PPOK) (Samosir, Nova Relida Ft et al., 2018). Menurut Word Health Organization (WHO) pada tahun 2015, Penyakit Paru Obstruktif Kronis (PPOK) merupakan penyebab utama keempat penyakit kronis dan kematian di Amerika Serikat dan diperkirakan akan menjadi peringkat ketiga pada tahun 2030 sebagai beban penyakit di seluruh dunia. Pada tahun 2030,diperkirakan 65 juta penduduk dunia mengalami PPOK sedang sampai berat, 3 juta lebih orang meninggal karena PPOK, dan menyumbang 6\% dari seluruh penyebab kematian (Huriah \& Wulandari Ningtias, 2017).

PPOK menjadi urutan pertama di Indonesia dalam kelompok penyakit paru yang memiliki angka kesakitan (35\%), dengan asma bronkial (33\%), kanker paru $(30 \%)$, dan lainnya $(2 \%)$. Prevalensi Penyakit Paru Obstruktif Kronik (PPOK) tertinggi di Indonesia terdapat di Nusa Tenggara Timur $(10,0 \%)$, Sulawesi Tengah $(8,0 \%)$, Sulawesi Barat $(6,7 \%)$, Jawa Timur $(3,6 \%)$,dan Sumatera Utara $(3,6 \%)$ (Silalahi, 2019). Namun jumlah Penderita Penyakit Paru Obstruktif paru (PPOK) tidak menutup kemungkinan akan mengalami peningkatan bersamaan dengan meningkatnya jumlah perokok, dan polusi udara yang melebihi ambang batas di Provinsi Sumatera Utara (Pasaribu, 2019).

Berdasarkan penelitian Elis Anggeria di Rumah Sakit TK II Putri Hijau (2016) survey awal yang didapatkan hasil jumlah penderita Penyakit Paru Obstruktif Kronik (PPOK) sebanyak 483 orang pada tahun 2012, 376 orang pada tahun 2013, 478 orang pada tahun 2014 dan 447 orang pada tahun 2015. terhitung mulai dari Januari 2017- Oktober 2017 di Rumah Sakit Putri Hijau ada sebanyak 51 jiwa. (Susyanti dkk, 2019). Menurut penelitian Sidabutar (2017) terdapat 110 orang penderita Penyakit Paru Obstruktif Kronik (PPOK) di Rumah Sakit Umum Pusat Haji Adam Malik (RSUP HAM) Medan dengan penderita laki laki sebanyak 80 orang dan penderita perempuan 30 orang. Berdasarkan hasil survei studi pendahuluan yang dilakukan diperoleh dari Rekam Medik Rumah Sakit GrandMed Lubuk Pakam diperoleh data penderita PPOK pada tahun 2018 sebanyak 170 orang, sedangkan pada bulan September sampai Desember 2019 berjumlah 50 orang.

Menurut The Gold For Chronic Obstruktif Lung Disease (GOLD) yang dimaksud dengan penyakit paru obstruktif kronik (PPOK) adalah penyakit paru yang dapat diatasi dan ditanggulangi dengan terhambatnya aliran udara yang bersifat terus menerus yang biasanya progresif dan berkaitan dengan meningkatnya respon inflamasi disaluran udara dan paruparu terhadap partikel atau gas yang berbahaya (GOLD, 2017). Pada penderita Penyakit Paru Obtruktif Kronik (PPOK) Penurunan kualitas hidup dikarenakan gejala yang terjadi penderita merasakan sesak napas, akibatnya penderita menjadi panik, takut dan frustasi sehingga penderita mengurangi aktifitas untuk menghindari sesak yang menyebabkan penderita tidak aktif. Akibat dari aktifitas yang rendah dapat mempengaruhi sistem musculoskeletal, respirasi, kardiovaskular dan lainnya. Kemampuan aktifitas fisik menurun dan dapat menyebabkan kapasitas 
fungsional menurun sehingga kualitas hidup penderita juga akan menurun (Al, 2015).

Menurut PERMENKES no. 65 tahun 2015 mencantumkan bahwa fisioterapi merupakan bentuk pelayanan kesehatan yang ditujukan kepada individu atau kelompok untuk mengembangkan, memelihara, dan memulihkan gerak dan fungsi tubuh sepanjang daur kehidupan dengan menggunakan penanganan secara manual, peningkatan gerak, peralatan (fisik, elektropeutis, dan mekanis), pelatihan fungsi dan komunikasi.

Pada penderita penyakit paru obstruktif kronik ada beberapa intervensi fisioterapi yang dapat dilakukan dalam mengatasi penurunan kemampuan hidup seperti pemberian Nebulizer, Heating seperti Short Wave Diatermi (SWD), Infra red, penguapan, Chest fisioterapi dan latihan. (purnomo,dkk 2017). Salah satu teknik pemberian Chest fisioterapi adalah dengan latihan pernapasan yang dapat dilakukan diantaranya latihan otot pernapasan inspirasi adalah Pursed Lips Breathing. Dan untuk meningkatkan kemampuan fungsional dilakukan dengan latihan pada setiap ekstremitas. (Samosir, dkk 2018)

Pursed Lips Breathing Exercise adalah latihan pernapasan yang bertujuan untuk memperbaiki dan mengatur frekuensi pola nafas sehingga penumpukan udara atau air tapping dapat berkurang, dengan mengurangi sesak nafas serta mengatur frekuensi nafas dengan mengatur ventilasi alveoli dan pertukaran gas dalam paru-paru (Qamila, Azhar, Risnah, 2019).

Beberapa

literaratur mengungkapkan bahwa penggunaan latihan ekstremitas dengan uji jalan 6 menit akan meningkatkan kapasitas fisik penderita. Hasil penelitian oleh
Pradana, dkk (2017) bahwa ada pengaruh latihan ektremitas yaitu ektremitas atas dan bawah terhadap peningkatan 6 Minutes Walking Test (6 MWT) dan $\mathrm{VO}_{2}$ maks yang sangat signifikat. Hasil penelitian dewi (2019) latihan pursed lips breathing mampu meningkatkan kualitas hidup pasien PPOK.

Berdasarkan latar belakang permasalahan diatas penulis tertarik untuk mengetahui lebih lanjut mengenai manfaat Pursed Lips Breathing dengan pursed lips breathing dan latihan ektremitas pada kasus Penyakit Paru Obstruktif kronik (PPOK). Maka penulis mengambil judul "Perbedaan Pursed Lips Breathing dengan Pursed Lips Breathing dan Latihan Ekstremitas Terhadap Kebugaran Pada Pasien Penyakit Paru Obstruktif Kronik (PPOK) Di Rumah Sakit GrandMed Lubuk Pakam 2020".

\section{METOdE PENELITIAN}

Penelitian ini dilaksanakan di RS GranMed lubuk pakam penelitian dilakukan pada bulan Desember- Juli 2020. Jenis penilitian ini adalah menggunakan quasi eksperimen dengan pendekatan control grup pretest dan post-test. Desain pararel digunakan untuk melihat adanya perbandingan antar dua kelompok (grup compersion) independent yaitu kelompok kontrol dan kelompok intervensi. Dalam penelitian ini, peneliti membagi responden menjadi dua kelompok yaitu kelompok dengan perlakuan pursed lips breathing dan latihan ektremitas sebagai kelompok intervensi dan kelompok dengan pelakuan pursed lips breathing, selanjutnya disebut sebagai kelompok kontrol. teknik pengambilan sampel (Purposive Sampling) dengan menggunakan rumus lameshow telah diketahui dari 50 populasi pasien PPOK 
terdapat 18 sampel pasien yang akan diteliti. kelompok, 9 orang kelompok intervensi dan 9 orang kelompok kontrol. Dengan Kriteria Inklusi 1) Pasien PPOK yang telah didiagnosa oleh dokter 2) Usia lebih dari 40 tahun keatas 3) Pasien bersedia untuk menjadi sampel penelitian dan Kriteria Eksklusi 1) Pasien memiliki riwayat TB paru 2) Pasien memiliki riwayat penyakit jantung, dan gangguan neurologis (seperti gangguan batang otak) 3) Pasien mengalami gangguan ortopedi sehingga tidak memungkinkan dilakukan six minutes walking test 4) Pasien tidak menyelesaikan terapi dikarenakan pasien terkena infeksi dari penyakit lain.

\section{Gambar 1. Alur Penelitian}

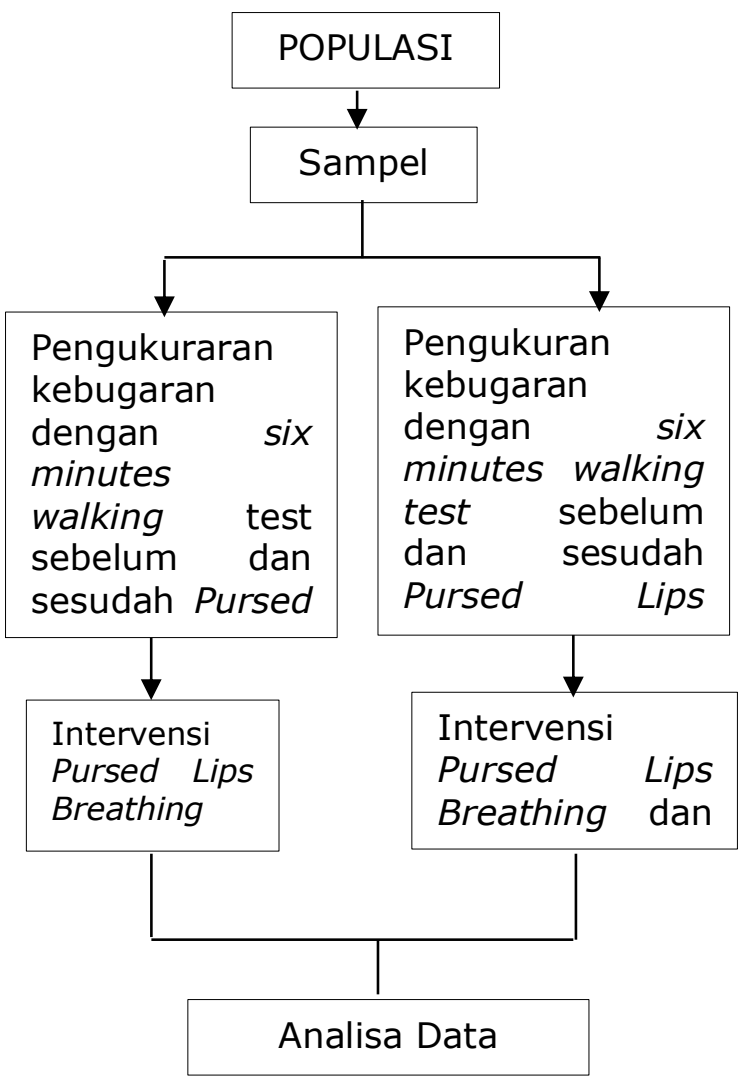

Metode intervensi fisioterapi yang diberikan.

\section{a. Pursed Lips Breathing}

Pursed Lips Breathing merupakan suatu teknik pernapasan, proses dimana pada saat ekspirasi dilakukan dengan menahan udara yang dikeluarkan melalui pengerutan bibir dengan tujuan untuk memperpanjang waktu saat ekspirasi. Pursed lips breathing dilakukan seolah-olah seperti meniup lilin, menimbulkan tekanan melalui saluran udara yang bertujuan untuk pengosongan paru-paru secara sempurna kemudian menggantikan dengan udara yang baru. Manfaat teknik ini mengurangi frekuensi bernafas dan sesak napas, membantu mengembalikan pola pernapasan normal setelah latihan, meningkatkan kemampuan Anda untuk melakukan berbagai aktivitas. Prosedur perlakuan pursed lips breathing ialah 1) Mengatur posisi pasien dengan duduk dibed atau kursi 2) Menginstruksikan pasien untuk rileks dengan melemaskan otot-otot leher dan bahu 3) Meletakkan salah satu tangan pasien di abdomen (tepat dibawah proc.sipoideus) dan satu tangan lainnya ditengah dada untuk merasakan adanya gerakan dada dan abdomen saat bernafas. 4) Tarik nafas dalam dengan hidung selama 4 detik hingga dada dan abdomen terasa terangkat maksimal kemudian jaga mulut agar tetap tertutup selama inspirasi dan tahan nafas selama 2 detik. 5) Lalu hembuskan nafas secara perlahan melalui bibir selama 4 detik sambil mengkontraksikan otot - otot abdomen. Menginstruksikan pasien untuk melakukan Pursed Lips Breathing sekitar 10 menit, dengan 6 kali pernapasan tiap siklusnya dan jeda antar siklus 2 detik, kemudian mengevaluasi kondisi responden setelah dilakukan intervensi. 6) Pursed Lips Breathing dilakukan 3 kali dalam sehari (pagi, sore, malam) selama 4 hari berturut-turut

b. Latihan Esktremitas

Latihan merupakan upaya untuk peningkatan kapasitas latihan, kekuatan otot,yang bertujuan untuk meningkatkan toleransi latihan yang didapat melalui peningkatan kapasitas oksidatif otot rangka yang mengakibatkan pengurangan produksii asam laktat dan perbaikan efisiensi gerakan yang menghasilkan beban 
kerja yang sama.latihan pada PPOK mampu mengurangi exercise incudes lactic acidocis dan perbaikan kapasitas oksidatif otot skeletal yang berpengaruh pada peningkatan $\mathrm{VO}_{2}$ maks. Peningkatan $\mathrm{VO}_{2}$ maks adalah tolak ukur untuk menentukan kebugaran pada pasien PPOK.

latihan pada ektremitas atas melibatkan semua anggota gerak atas dengan gerakan seperti shoulder flexion dan ekstension, shoulder abduction dan adduction, Dan pada ekstremitas bawah melibatkan semua aggota gerak bagian bawah seperti hip flexion dan extension, hip abduction dan adduction dan sebagainya. Prosedur pelaksanaan latihan ekstremitas adalah 1) Posisikan pasien dalam keadaan nyaman dan rileks 2) Contohkan gerakan yang akan dilakukan oleh pasien 3) Lalu lakukan gerakan pada tiap ektremitas seperti flexion, extension shoulder serta pada extremitas bawah 4) Lakukan gerakan dengan 8 kali pengulangan pada setiap gerakan.

\section{Hasil Penelitian}

a. Distribusi Data Berdasarkan Usia Dan Jenis Kelamin Kelompok Kontrol (Pursed Lips Breathing ) Dan Intervensi (Pursed Lips Breathing Dan Latihan Ekstremitas)

Tabel 3.1: Karakteristik Responden

\begin{tabular}{ccccc}
\hline Variabel & \multicolumn{3}{c}{$\begin{array}{l}\text { Kelompok } \\
\text { Kontrol } \\
\text { (Pursed Lips } \\
\text { Breathing ) }\end{array}$} & \multicolumn{2}{c}{$\begin{array}{l}\text { Intervensi } \\
\text { (Pursed Lips } \\
\text { Breathing } \\
\text { dan Latihan } \\
\text { Ekstremitas) }\end{array}$} \\
\hline Usia & Jumlah & $\%$ & Jumlah & $\%$ \\
$46-50$ & 1 & 11,1 & 2 & 22,2 \\
$51-55$ & 3 & 33,3 & 1 & 11,1 \\
$56-60$ & 1 & 11,1 & 3 & 33,3 \\
$61-65$ & 2 & 22,2 & 3 & 33,3 \\
$66-70$ & 2 & 22,2 & - & - \\
Total & 9 & 100 & 9 & 100 \\
Jenis kelamin & & & \\
Laki- & 6 & 66,7 & 7 & 77,8 \\
laki & 3 & 33,3 & 2 & 22,2 \\
Perem- & 3 & &
\end{tabular}

\begin{tabular}{ccccc}
\hline puan & & & & \\
\hline Total & 9 & 100 & 9 & 100 \\
\hline
\end{tabular}

Berdasarkan tabel 3.1 dapat dilihat distribusi sampel menurut usia tertinggi pada perlakuan kelompok kontrol ialah responden yang berusia 51-55 sebanyak 3 orang $(33,3 \%)$, dan sampel menurut usia terendah yaitu usia 46-50 sebanyak 1 orang $(11,1 \%)$, usia $56-60$ sebanyak 1 orang $(11,1 \%)$. Sedangkan distribusi sampel menurut usia tertinggi pada kelompok intervensi yaitu responden yang berusia 56-60 sebanyak 3 orang (33,3\%), usia $61-65$ sebanyak 3 orang $(33,3 \%)$, dan sampel menurut usia terendah yaitu usia 51-55 sebanyak 1 orang $(11,1 \%)$. Sedangkan distribusi sampel menurut jenis kelamin pada perlakuan kelompok kontrol responden yang berjenis kelamin lakilaki sebanyak 6 orang $(66,7 \%)$, jenis kelamin perempuan sebanyak 3 orang $(33,3 \%)$. Sedangkan distribusi sampel menurut jenis kelamin pada perlakuan kelompok intervensi responden yang berjenis kelamin laki-laki sebanyak 7 orang $(77,8 \%)$, berjenis kelamin perempuan 2 orang $(22,2 \%)$.

3.2. Rerata Kebugaran Sebelum Dan Sesudah Perlakuan Kelompok Kontrol (Pursed Lips Breathing) Pada Pasien PPOK

\begin{tabular}{cccc}
\hline $\begin{array}{c}\text { Kebugar } \\
\text { an }\end{array}$ & Mean & METs & $\begin{array}{c}\text { Std. } \\
\text { Deviasi }\end{array}$ \\
\hline Sebelum & 195,00 & 2,44 & 8,292 \\
sesudah & 212,22 & 2,47 & 10,341 \\
\hline
\end{tabular}

Berdasarkan tabel 3.2 diatas maka dapat diketahui bahwa hasil analisis rerata kebugaran sebelum perlakuan yaitu 195,00 dikonversikan dengan METs 2,44. Standart Deviasi 8,292. Sedangkan rerata kebugaran sesudah yaitu 212,22 dikonversikan dengan METs 2,47. Standart Deviasi 10,341

b. Rerata Kebugaran Sebelum Dan Sesudah Perlakuan Kelompok Intervensi (Pursed Lips Breathing dan Latihan Ekstremitas) Pada Pasien PPOK 


\begin{tabular}{lccc}
\hline Kebugaran & Mean & METs & $\begin{array}{c}\text { Std. } \\
\text { Deviasi }\end{array}$ \\
\hline sebelum & 200,56 & 2,45 & 8,457 \\
sesudah & 265,56 & 2,56 & 9,825 \\
\hline
\end{tabular}

Berdasarkan tabel 3.3 diatas maka dapat diketahui bahwa hasil analisis rerata kebugaran sebelum perlakuan yaitu 200,56 dikonversikan dengan METs 2,45. Standart Deviasi 8,457 dan Standart Error 2,819. Sedangkan rerata sesudah perlakuan yaitu 265,56 dikonversikan dengan METs 2,56. Standart Deviasi 9,825.

c. Rerata Perbedaan Kebugaran Sebelum dan Sesudah Perlakuan Kelompok Kontrol (Pursed Lips Breathing) dan Intervensi (Pursed Lips Breathing dan Latihan Ekstremitas) Pada Pasien PPOK

\begin{tabular}{llllc}
\hline Kebugaran & Mean & $\begin{array}{c}\text { Std. } \\
\text { Deviasi }\end{array}$ & t & -value \\
\hline Kontrol & 17,222 & 11,487 & 4,498 & 0,002 \\
Intervensi & 65,000 & 11,990 & 16,264 & 0,000 \\
\hline
\end{tabular}

Hasil uji statistik diperoleh pada kelompok kontrol mean 17,22 dengan SD 11,487 dan $p$-value $a<(0,002<$ $0,05)$. Dan pada kelompok intervensi mean 65,000 dengan SD 11,990 dan $p$ value $a<(0,000<0,05)$. maka dapat disimpulkan bahwa adanya perbedaan kebugaran sebelum dan sesudah diberikan Pursed Lips Breathing Dengan Pursed Lips Breathing Dan Latihan Ekstremitas Terhadap Kebugaran Pada Pasien PPOK.

d. Pengaruh Rerata Perbedaan Kebugaran Kelompok Kontrol (Pursed Lips Breathing) Dan Intervensi (Pursed Lips Breathing Dan Latihan Ekstremitas) Pada Pasien PPOK

\begin{tabular}{ccc}
\hline Kebugaran & $\begin{array}{c}\text { Mean } \\
\text { difference }\end{array}$ & $\begin{array}{c}\text { Sig(2- } \\
\text { tailed) }\end{array}$ \\
\hline $\begin{array}{c}\text { Kelompok } \\
\text { kontrol } \\
\text { dan }\end{array}$ & 47.778 & 0,000 \\
intervensi & & \\
\hline
\end{tabular}

Berdasarkan pengolahan data yang yang telah dilakukan uji statistic dengan menggunakan uji independent $t$-test diperoleh $p$-value a $<(0,000<$ $0,05)$, maka dapat disimpulkan bahwa hipotesa penelitian ini diterima yaitu "Ada Perbedaan Pursed Lips Breathing Dengan Pursed Lips Breathing Dan Latihan Ekstremitas Terhadap Kebugaran Pada Pasien Penyakit Paru Obstruktif Kronik (PPOK).

\section{PEMBahasan}

\subsection{Karateristik Responden}

Interval usia reponden dalam penelitian ini adalah usia 46-70 tahun. Dengan perlakuan kelompok kontrol responden yang berjenis kelamin laki-laki sebanyak 6 orang $(66,7 \%)$, jenis kelamin perempuan sebanyak 3 orang $(33,3 \%)$. Dengan reponden pada perlakuan kelompok intervensi yang berjenis kelamin laki-laki sebanyak 7 orang $(77,8 \%)$, berjenis kelamin perempuan 2 orang (22,2\%). Hasil menunjukkan bahwa Penyakit paru obstruktif kronik (PPOK) akan menimbulkan dampak negatif terhadap kualitas hidup penderita, termasuk pasien yang berumur lebih dari 40 tahun akan mengakibatkan gangguan pada penderitanya.

Hasil penelitian Rosa, \& Mjw (2016) menunjukan bahwa karateristik responden berdasarkan jenis kelamin paling banyak adalah laki-laki sebanyak 22 orang dan berjenis kelamin perempuan 3 orang. Hasil penelitian ini juga sejalan dengan penelitian yang dilakukan di RSUP Dr. M. Djamil pada tahun 2016 bahwa tingkat keparah penyakit paru obstruktif kronik (PPOK) lebih banyak dialami oleh laki laki karena derajat merokok (Naser, dkk. 2016).

4.2 Perbedaan Pursed Lips Breathing dengan pursed lips breathing dan latihan ekstremitas 
Pursed lips breathing merupakan latihan pernapasan yang bertujuan untuk memperbaiki dan mengatur frekuensi pola nafas sehingga penumpukan udara atau air tapping dapat berkurang, dengan mengurangi sesak nafas serta mengatur frekuensi nafas dengan mengatur ventilasi alveoli dan pertukaran gas dalam paru-paru dan meningkatkan aktifitas fungsional . Bernafas pursed lips breathing menyebabkan proses ekspirasi secara panjang. Dengan inspirasi dalam dan ekspirasi panjang akan menyebabkan peningkatan kekuatan kontraksi otot intra abdomen sehingga tekanan intra abdomen meningkat melebihi pada saat ekspirasi pasif. Tekanan intra abdomen yang meningkat lebih kuat maka akan meningkatkan pergerakan diafragma ke atas membuat rongga thorak semakin mengecil. Rongga thorak yang semakin mengecil ini mengakibatkan tekanan intra alveolus semakin meningkat sehingga melebihi tekanan udara atmosfer. Ekspirasi panjang saat bernafas pursed lips breathing exercise juga akan mengakibatkan penyempitan jalan nafas berkurang sehingga resistensi pernafasan juga menurun.

Penambahan Latihan estremitas pada pursed lips berathing Latihan fisik telah terbukti mampu meningkatkan kapasitas oksidatif otot rangka yang memberikan dampak positif berupa berkurangnya produksi asam laktat, sehingga diharapkan mampu memperbaiki tingkat konsumsi oksigen jaringan. Secara umum, penelitian ini dimaksudkan untuk menilai pengaruh latihan ketahanan ekstremitas bawah dan atas terhadap kebugaran pada penderita PPOK.

Perubahan akibat latihan terjadi pada sistem kardiorespirasi terutama sistem tranfor oksigen, yaitu sistem sirkulasi, respirasi, dan jaringan ditubuh. Sistem ini bekerja secara terpadu yang akan menyebabkan perubahan-perubahan ukuran jantung, penurunan denyut nadi, peningkatan isi sekuncup, peningkatan volume darah dan kadar hemoglobin, peningkatan $\mathrm{VO}_{2}$ maks dan perubahan pola pernapasan. Peningkatan $\mathrm{VO}_{2}$ maks adalah tolak ukur untuk menentukan kebugaran pada pasien PPOK. dengan betambahnya jarak tempuh (six minutes walking test) yang dikonversikan ke dalam METs. .

Asumsi menurut penulis terhadap penelitian ini bahwa terdapat perbedaan pursed lips breathing dengan pursed lips breathing dan latihan ekstremitas terhadap kebugaran pada pasien PPOK. Hal ini dikarenakan adanya penambahan latihan estremitas pada pursed lips berathing akan meningkatkan kekuatan oksidatif otot rangka yang memberikan dampak positif berupa berkurangnya produksi asam laktat, sehingga diharapkan mampu memperbaiki tingkat konsumsi oksigen jaringan sehingga pasien mampu meningkatkan kebugaran.

Pursed lips breathing dengan pursed lips breathing dan latihan ektremitas sama sama mampu meningkatkan nilai kebugaran pada pasien ppok, namun ada perbedaan yang signifikan dimana adanya penambahan latihan ekstremitas pada pursed lips breathing dapat mengakibatkan paru lebih terlatih yang dapat meningkatkan oksigen sehingga penderita dapat meningkatkan aktifitas fungsionalnya.

\section{KESIMPULAN}

Berdasarkan hasil uji statistik pada kelompok intervensi yaitu perlakuan Pursed lips Breathing dan latihan ekstremitas $p$ - value $a<(0,000<$ $0,05)$, sedangkan pada perlakuan 
kelompok kontrol Pursed Lips Breathing $\mathrm{p}$ - value $\mathrm{a}<(0,002<0,05)$, dengan uji independent pada kelompok kontrol dan intervensi diperoleh $p$-value a $<$ $(0,000<0,05)$, maka dapat disimpulkan bahwa Ada Perbedaan Pursed Lips Breathing Dengan Pursed Lips Breathing Dan Latihan Ekstremitas Terhadap Kebugaran Pada Pasien Penyakit Paru Obstruktif Kronik (PPOK).

\section{SARAN}

\subsection{Bagi Institusi}

Diharapkan teknik Pursed Lips Breathing dan latihan Ekstremitas menjadi bahan ajar tambahan pada mahasiswa tentang penanganan fisioterapi dalam kasus penyakit paru obstruktif kronik (PPOK) khususnya dalam meningkatkan kebugaran.

\subsection{Bagi Rumah sakit}

Diharapkan dapat menjadi referensi dalam pemberian tindakan fisioterapi pada pasien penyakit paru obstruktif kronik (PPOK).

\subsection{Bagi Peneliti}

Untuk peneliti berikutnya dapat melakukan jumlah sampel yang lebih besar dari penelitian ini dan waktu penelitian yang lebih lama dari penelitian ini agar hasil yang didapatkan lebih maksimal.

\subsection{Bagi Profesi Fisioterapi}

Dapat dijadikan bahan acuan pembuatan SOP (standard operasional prosedur) dalam penanganan khusus penyakit paru obstruktif kronik (PPOK)

\section{DAFTAR PUSTAKA}

Al, muthmainnah et. (2015). Gambaran K ualitas Hidup Pasien Ppok Stabil Di Poli Paru Rsud Arifin Achmad Provinsi Riau Dengan Menggunakan Kuesioner Sgrq. Jom Fk, 2(2), 1-20. https://doi.org/10.1017/CBO978110 7415324.004

Arifin, Z. (2018). Pengaruh Latihan Senam Kebugaran Jasmani (Skj)
Terhadaptingkat Kebugaran Siswa Kelas $V$ Di Min Donomulyo Kabupaten Malang. Journal ALMUDARRIS, 1(1), 22.

Dewi. (2019). Pengaruh Pemberian Latihan Pursed Lips Breathing ( Plb ) Terhadap Kualitas Hidup Klien Penyakit Paru Obstruktif Kronik ( PPOK ) Dewi Astuti Pasaribu Program Studi Profesi Ners, Sekolah Tinggi IImu Kesehatan Sumatera Utara. 195-202.

Families, T. (2019). Managing Your TE Breathing and Saving.

GOLD. (2017). Global Initiative for Chronic Obstructive. GOLD, Global Obstructive Lung Disease, 1-44.

Huriah, T., \& Wulandari Ningtias, D. (2017). Pengaruh Active Cycle of Breathing Technique Terhadap Peningkatan Nilai Vep1, Jumlah Sputum, Dan Mobilisasi Sangkar Thoraks Pasien Ppok. Indonesian Journal of Nursing Practices, 1(2), 44-54.

Issues, S., Test, M. W., Equipment, R., \& Preparation, P. (2002). American Thoracic Society ATS Statement: Guidelines for the Six-Minute Walk Test.

Pradana, A., Tarigan, A. P., Mediyanti, T., Mutiara, E., \& Pandia, P. (2017). Pengaruh Latihan Ketahanan Ekstremitas Bawah terhadap Nilai Ambilan Oksigen Maksimal ( VO 2 Max ) pada Penyakit Paru Obstruktif Kronik Effects of Lower Limb Endurance Training on Maximal Oxygen Uptake ( VO 2 max ) in Chronic Obstructive Pulmonary Disease. 37(4), 283-287.

Qamila,Azhar,Risnah, I. (2019). EFEKTIVITAS TEKNIK PURSED LIPSBREATHING PADA PASIEN PENYAKIT PARU OBSTRUKSI KRONIK ( PPOK ): STUDY SYSTEMATIC REVIEW Data dari Profil Dinas Kesehatan Provinsi Sulawesi 
Selatan menyatakan PPOK. 12, 137145.

Samosir, Nova Relida Ft, S. S. T., Dian, M. F., Sari, C., \& Pd, M. (2018). Pengaruh Pemberian Pursed Lips Breathing Dan Six Minute walking Test Dengan Infra Red Dan Six Minute Walking Test Dapat Meningkatkan Kualitas Hidup Pada Kondisi Penyakit Paru Obstruktif Kronik ( Ppok ) Jurnal Ilmiah Fisioterapi ( JIF ) Volume 1 nomor $02, .1$.

Susyanti, D., Parlagutan, M. T., \& Marbun, S. (2019). PASIEN TB PARU DI RUMAH SAKIT TK II PUTRI HIJAU MEDAN TAHUN 2018 Case study of the Fulfillment of Airway Clearance in Pulmonary TB Patients at the Putri Hijau Hospital II Medan in 2018. Jurnal Riset Hesti Medan, 4(1), 2332.

Soewito, F. (n.d.). Latihan Penguatan pada Rehabilitasi Penyakit Paru Obstruktif Kronik: Proses Sistemik dan Biomolekuler. September 2016, 551-558.

Russell, R., Norcliffe, J. Bafadhel, M. 2012. Chronic obstructive pulmonary disease: management of chronic disease. Elsevier Ltd. All rights reserved. Medicine 40:5

Pengaruh Latihan Ketahanan Ekstremitas Bawah terhadap Nilai Ambilan Oksigen Maksimal ( vo 2 Max ) pada Penyakit Paru Obstruktif Kronik Effects of Lower Limb Endurance Training on Maximal Oxygen Uptake ( VO 2 max ) in Chronic Obstructive Pulmonary Disease. 37(4), 283-287. 